\title{
Introduction: tourism and development - towards a research agenda
}

Richard Sharpley and David Harrison

\section{Introduction}

The raison d'etre of tourism is development. In other words, since the 1950 - not coincidentally, from the time when 'development' first became established as a global project in an emerging post-colonial world (Rist 2014) - tourism at both the national (domestic) and international scale has primarily been considered an effective catalyst of economic and social development. Indeed, almost four decades ago this role of tourism was officially endorsed by the World Tourism Organization (now United Nations World Tourism Organization, or UNWTO) in its Manila Declaration: 'world tourism can contribute to the establishment of a new international economic order that will help eliminate the widening economic gap between developed and developing countries and ensure the steady acceleration of economic and social development and progress, in particular in developing countries' (WTO 1980, p.1). Since then, not only has the UNWTO supported the development of tourism through knowledge generation and dissemination, policy guidance and more direct intervention (UNWTO 2017a) but also tourism itself has come to occupy a prominent position in the development policies and processes of an increasing number of countries and regions (Telfer \& Sharpley 2016). In some cases, particularly where few if any other viable alternatives exist, especially small island states, it may be an option of 'last resort' (Brown 1998; Harrison 2001; Harrison \& Prasad 2013; Lea 1988); in other cases, it has been employed as a means of diversifying economies dependent on a single sector, such as oil (Morakabati et al. 2014; Sharpley 2002), of stimulating the regeneration of peripheral rural areas (Gannon 1994; Roberts \& Hall 2001) and postindustrial cities (Law 1992; Murphy \& Boyle 2006), or more generally contributing to economic and social development (Sharpley \& Telfer 2015). Irrespective of the context, however, tourism has, over the last half century or so, become a ubiquitous agent of development in almost every corner of the globe.

It is perhaps not surprising, therefore, that academic attention has long been paid to the relationship between tourism and development. Initially, such attention adopted a typically critical stance. That is, in contrast to the enthusiasm with which tourism was embraced by destinations eager to exploit the burgeoning demand for tourism, particularly from the late 1960 s and with the emergence of international 
tourism on a relatively mass scale, early studies began to question its alleged developmental benefits. For example, Diamond (1977), drawing on research in Turkey, concluded that tourism did not necessarily represent a panacea to the economic problems facing many developing countries in particular, whilst a number of now seminal texts challenged tourism's developmental contribution more generally (de Kadt 1979; Turner \& Ash 1975; Young 1973). Moreover, such criticism continued into the early 1980s, albeit more specifically from a political-economic perspective, with some arguing that tourism's developmental contribution was restricted by the inherent power relations within the international tourism sector that served to perpetuate a condition of dependency in destinations (Britton 1982; Høivik \& Heiberg 1980; Husbands 1981).

However, the pendulum soon began to swing in the opposite direction as academic attention became focused more positively on means of enhancing the benefits of tourism to destinations. For example, reflecting the emergence of the alternative development paradigm (Pieterse 1998), alternative tourism, a blanket term applied to forms of tourism that allegedly offer an alternative to the perceived problems associated with mass tourism, gained widespread support during the latter half of the 1980s (Butler 1990; Smith \& Eadington 1992), whilst the roots of the now popular concept of community-based tourism (CBT), drawing on the 'bottom-up' or grassroots philosophy of alternative development, also date back to this time (Murphy 1983, 1985). Thus, over a period of some 30 years, theory and understanding of the relationship between tourism and development progressed, according to Jafari (1989), through three stages: an initial advocacy stage, extolling the benefits of tourism, superseded by a cautionary stage that highlighted the negative consequences of tourism and then an adaptancy stage manifested in the alternative tourism movement.

Significantly, since the early 1990 we have witnessed the advent and subsequent maturation of a fourth, knowledge stage (Jafari 1989) during which understanding of tourism's developmental processes has expanded and deepened. Specifically, the locating of tourism within the conceptual framework of sustainable development provided - and continues to provide - a fruitful though controversial context for research into tourism and development (Mowforth \& Munt 2016; Sharpley 2009), as well as the basis for much tourism planning and policy (though not necessarily implementation) in practice. At the same time, following the lead of a number of notable studies that established an initial link between the fields of tourism and development studies (for example, Brohman 1996; Harrison 1992; Opperman \& Chon 1997), a more nuanced, theoretically informed understanding of tourism and development benefiting from contributions from a variety of disciplines has evolved. Indeed, knowledge and understanding of tourism as a social and economic phenomenon in general, as well as of its potential to contribute to development in particular, has advanced rapidly over the last two decades.

Nevertheless, tourism is dynamic, as both the demand for and supply of tourism are constantly transformed in response to economic, socio-cultural and technological 
change, and the external world within which the so-called tourism 'system' (Leiper 1990) is located and with which it interacts is also in a constant state of flux. A variety of influences and processes, from shifts in the global political-economic landscape to such challenges as climate change, have direct consequences for tourism, whilst tourism may also contribute to these processes. And more specifically in the context of this book, understandings of development, how it may be measured, the policies for and goals of development and the mechanisms for its achievement are equally dynamic. For example, once considered to be synonymous with economic growth (Mabogunje 1980), the concept of development has evolved into a broader concern for human well-being (Knutsson 2009) with specific global development objectives defined in the UN's 17 Sustainable Development Goals (UN 2017). Similarly, theories of development, or development paradigms, have also evolved, reflecting not only greater knowledge and understanding of developmental opportunities and challenges but also transformations in the global political economy (de Janvry \& Sadoulet 2016; Todaro \& Smith 2014).

The concept of development (as the explicit purpose of promoting tourism) is considered in more detail later in this chapter. The important point here, however, is that although ever increasing academic attention has been paid to the relationship between tourism and development, that relationship continues to change as both tourism and the challenges of development also undergo change. As a consequence, new questions arise and new gaps in knowledge emerge. For example, are typically growth-focused tourism policies becoming increasingly detrimental to destination development? Can mass forms of tourism in fact generate more benefit to the destination than alternative forms of tourism? Does the role of the state in supporting tourism-induced development require reconsideration? How effective is tourismrelated philanthropy in contributing to development? Is CBT a realistic development policy? And, to what extent can tourism contribute to what is still the most pressing development challenge, namely poverty reduction? In short, despite the more recent advances in knowledge and understanding of the relationship between tourism and development, there exists the need for further research or, more precisely, for an agenda for research that addresses these and other questions and issues.

The purpose of this book is to establish such an agenda. That is, it sets out to identify and justify gaps in extant knowledge and understanding of tourism and development and, in so doing, to propose a number of themes and issues that would benefit from further research. As such, it is not the intention to suggest specific research projects; rather, the aim of the book is to identify potential avenues of research that might be followed from a variety of disciplinary or contextual perspectives, thereby ultimately contributing to the overall tourism and development body of knowledge. Hence, the remainder of this introductory chapter is concerned with establishing the background to this research agenda, first summarizing the factors that justify the widespread adoption of tourism as an agent of development before going on to review briefly the evolution of the concept of development and development theory. It then highlights key themes and perspectives within the extent research in tourism and development as a basis for introducing the chapters that comprise this book. 


\section{Development: why tourism?}

As noted above, tourism has not only enjoyed long recognition and endorsement as a potentially valuable catalyst of development, but also this role is widely manifested in practice. By the early 1990s, it was observed that tourism had been adopted as 'an important and integral element of . . . development strategies' (Jenkins 1991a, p.61) in many countries around the world. Unsurprisingly, however, it is primarily in the context of developing countries that: 'the development of tourism has long been seen as both a vehicle and a symbol of ... progress and modernization' (Roche 1992, p. 566). Consequently, attention was, and continues to be, focused largely on tourism and development in the developing world. This is not to say, of course, that tourism has not been embedded in the development and regeneration policies of modern, industrialized nations; in Europe, for example, tourism's role in economic development enjoys a long history (Williams \& Shaw 1991) whilst nowadays there is much evidence of national and supranational policy responses across the continent to the developmental opportunities afforded by tourism (Costa et al. 2013; EU n.d.). Nevertheless, in academic circles at least, it is developing countries that have benefited most from research, immediately pointing to a potential gap in extant knowledge (see Chapter 11).

Irrespective of the context, however, the principal reason for tourism to be adopted as a development strategy has always been its perceived economic contribution (Mihalič 2015; Sinclair 1998). Indeed, there can be no doubting the economic value of tourism on a global scale. In 2016, for example, worldwide international tourism receipts (payments for all goods and services in the destination and for international transport) amounted to US\$1,220 million (UNWTO 2017b). If domestic tourism is also taken into account then, according to the World Travel and Tourism Council (WTTC 2016), the total direct economic contribution of tourism amounts to around US\$2.3 trillion, or 3 per cent of global gross domestic product (GDP), rising to over US\$7 trillion (9.8 per cent of GDP) if tourism's indirect contribution is also taken into account.

Such remarkable figures deserve to be treated, perhaps, with a degree of caution. Nevertheless, as one of the world's largest export sectors, international tourism represents a significant source of income and foreign exchange earnings, particularly for developing countries and, most especially, for many small island states that lack a range of natural resources and for which tourism can represent an overwhelming percentage of their GDP. Indeed, even though the absolute number of international tourists visiting such destinations is but a tiny percentage of international trips, small island states have long constituted the vast majority of world destinations most economically dependent on international tourism (Harrison 2001, p. 10; Harrison \& Prasad 2013). Equally, it may also make a vital contribution to any country's balance of payments, not least to the travel account of major tourism-generating countries. In 2016, for example, international tourists in the UK spent $£ 22.5$ billion, around half of the $£ 43.8$ billion spent by UK residents on overseas visits (ONS 2017). At the same time, tourism is widely considered to be a labour-intensive sector and may be 
a significant source of employment in destination areas, whether direct or indirect. Again, according to the WTTC (2016), tourism supports around 284 million jobs worldwide, or almost 10 per cent of employment although, as discussed later in this chapter, issues surrounding tourism-related employment remain surprisingly underrepresented in the literature (see Chapter 10).

It should be noted, of course, that tourism may also incur significant economic costs (Wall \& Mathieson 2006), hence the 'tourism development dilemma' (Telfer \& Sharpley 2016) that many destinations face. Nevertheless, except in those instances where tourism represents the only viable choice, it may be assumed that, generally, destination administrations make a positive decision to integrate tourism into their development strategies in the expectation that the economic benefits will outweigh the costs. And indeed, there are innumerable examples around the world of cities, rural regions, islands, coastal resorts and entire nations where that expectation has proved to be correct, although the challenge of so-called 'overtourism', long prophesied in the literature, suggests that excessive emphasis tends to be placed on economic gain above other developmental needs. There are, however, a number of other factors, discussed at some length in the literature, that serve to enhance the attraction of tourism as a development option (Sharpley 2015), as follows.

\section{Tourism is a growth sector}

Tourism, particularly international tourism, is characterized by a history of remarkable growth. In 1950, the year that international statistics were first collated and published, just over 25 million international arrivals were recorded. Over the following six decades, international tourism grew, in terms of arrivals, at an average annual rate of 6.2 per cent, whilst receipts achieved an average annual growth rate of more than 10 per cent. As can be seen from Table 1.1, rapid growth in arrivals and receipts was achieved throughout the latter half of the twentieth century; at the turn of the new millennium, almost 690 million arrivals were recorded and, just over a decade later, in 2012, the 1 billion mark was surpassed for the first time. Since then, the growth in arrivals has continued although it should be noted that, on a decade-by-decade basis, the growth rate in both arrivals and receipts has not only steadily declined but also continues to do so (see Table 1.2). For example, the average annual growth rate in arrivals between 2010 and 2015 was 3.9 per cent (UNWTO 2016). Although recent figures suggest that an annual growth rate of around 4 per cent may be maintained into the future, it is unlikely that the UNWTO's long-standing prediction of 1.6 billion arrivals and receipts of over US $\$ 2$ trillion by 2020 will be achieved (WTO 1998).

Three other points should also be noted. First, international tourism is susceptible to a variety of external factors and, at times, has experienced low or even negative growth worldwide. Following the events of 9/11, for example, an overall decline in global tourist arrivals was recorded in 2001 whilst, similarly, a decline also occurred in 2009 as a result of the global financial crisis. However, such falls are rare with more frequent declines typically experienced at the regional or destinational level, 
Table 1.1 International tourist arrivals and receipts, 1950-2016

\begin{tabular}{lrrrrr}
\hline Year & $\begin{array}{c}\text { Arrivals } \\
\text { (million) }\end{array}$ & $\begin{array}{r}\text { Receipts } \\
\text { (US\$bn) }\end{array}$ & Year & $\begin{array}{r}\text { Arrivals } \\
\text { (million) }\end{array}$ & $\begin{array}{r}\text { Receipts } \\
\text { (US\$bn) }\end{array}$ \\
\hline 1950 & 25.3 & 2.1 & 2000 & 687.0 & 481.6 \\
1960 & 69.3 & 6.9 & 2001 & 686.7 & 469.9 \\
1965 & 112.9 & 11.6 & 2002 & 707.0 & 488.2 \\
1970 & 165.8 & 17.9 & 2003 & 694.6 & 534.6 \\
1975 & 222.3 & 40.7 & 2004 & 765.1 & 634.7 \\
1980 & 278.1 & 104.4 & 2005 & 806.1 & 682.7 \\
1985 & 320.1 & 119.1 & 2006 & 847.0 & 742.0 \\
1990 & 439.5 & 270.2 & 2007 & 903.0 & 856.0 \\
1991 & 442.5 & 283.4 & 2008 & 917.0 & 939.0 \\
1992 & 479.8 & 326.6 & 2009 & 882.0 & 851.0 \\
1993 & 495.7 & 332.6 & 2010 & 940.0 & 927.0 \\
1994 & 519.8 & 362.1 & 2011 & 995.0 & $1,042.0$ \\
1995 & 540.6 & 410.7 & 2012 & $1,035.0$ & $1,075.0$ \\
1996 & 575.0 & 446.0 & 2013 & $1,087.0$ & $1,159.0$ \\
1997 & 598.6 & 450.4 & 2014 & $1,130.0$ & $1,252.0$ \\
1998 & 616.7 & 451.4 & 2015 & $1,184.0$ & $1,196.0$ \\
1999 & 639.6 & 465.5 & 2016 & $1,235.0$ & $1,220.0$ \\
\hline
\end{tabular}

Source: Adapted from UNWTO data.

Table 1.2 International tourism arrivals and receipts growth rates, 1950-2000

\begin{tabular}{lcc}
\hline Decade & $\begin{array}{c}\text { Arrivals } \\
\text { (average annual increase \%) }\end{array}$ & $\begin{array}{c}\text { Receipts } \\
\text { (average annual increase \%) }\end{array}$ \\
\hline $1950-60$ & 10.6 & 12.6 \\
$1960-70$ & 9.1 & 10.1 \\
$1970-80$ & 5.6 & 19.4 \\
$1980-90$ & 4.8 & 9.8 \\
$1990-2000$ & 4.2 & 6.5 \\
\hline
\end{tabular}

Source: Adapted from UNWTO 2005.

sadly often as a result of terrorist activity. For example, following two separate terrorist attacks against tourists in Tunisia in 2015, the country's tourism sector suffered a serious decline for two years with international arrivals only beginning to increase again in late 2017.

Second, international tourism has traditionally been polarized and regionalized (Shaw \& Williams 1994). That is, the major flows of international tourists have 
tended to be between particular places (for example, between Northern and Southern Europe and between North America and the Caribbean) and within particular regions; until very recently, Europe accounted for more than half of all international tourist arrivals. This dominance is gradually changing with the Asia and Pacific region in particular claiming a larger share of global arrivals and the emergence of China as the world's largest international tourism generator (Harrison 2016), yet the overall figures mask a continuing inequity in the share of international tourism. In other words, the growth of international tourism has not been universal, with implications for many countries most in need of development.

And third, tourism data collated and presented on a worldwide basis exist only for international tourism. Although many individual countries, particularly in the developed world, collect domestic tourism data, few if any attempts have been made to undertake international comparisons, one notable exception being Bigano et al.'s (2007) study. Even this is limited in scope and provides no indication of the overall scale and growth of domestic tourism on a global basis yet, in addition to clear evidence that, generally, it is of significantly greater economic value than international tourism (and hence an equally if not more powerful economic growth catalyst), it would be safe to assume that domestic tourism has also grown consistently. Overall, then, despite a slowing growth rate and inequities in the share of that growth, tourism (both international and domestic) remains a safe development option.

\section{Tourism redistributes wealth}

It has long been recognized that one of the principal challenges to development is inequality both within and between nations (Seers 1969). Indeed, although significant progress has been achieved in recent years in reducing poverty around the world, particularly during the Millennium Development Goals programme (UN 2015), there is evidence that such inequality is actually on the increase (UN 2017). However, as a potentially effective means of transferring wealth from richer countries or regions to poorer, less developed or peripheral areas, tourism may contribute to the alleviation of inequality, whether through direct tourist expenditure on goods and services in the destination (with spending in the local informal economy in particular transferring wealth to the poor) or through foreign direct investment in the local tourism sector. Moreover, at the national scale, domestic tourism may play a significant role in the redistribution of wealth in both developed and developing countries. On the one hand, however, this redistributive effect may be limited by the nature and scale of tourism in the destination; for example, all-inclusive resort-based tourism is considered to restrict the spread of wealth locally (Freitag 1994). On the other hand, additional, philanthropic expenditures and activities beyond the tourism sector may help relieve inequalities (Chapter 5 ).

\section{Backward linkages}

While in the destination, tourists inevitably require a variety of goods and services, including accommodation, food and beverages, local transport, entertainment, 
souvenirs and so on. Hence, in principle, tourism offers significant opportunities for individuals and businesses within the local economy to respond to these needs, such as through the provision of food to hotels and restaurants (Telfer \& Wall 2000; Torres 2003) or the production of arts and crafts for sale to tourists. Again, however, the extent to which these backward linkages can be successfully developed and exploited is dependent on a variety of factors, including the diversity and maturity of the local economy, the availability of finance and the volume and quality of locally produced goods. In some cases, the failure or inability to establish backward linkages may result in a high level of 'leakage', whereby earnings from tourism are spent on imports to service tourists' needs (see, for example, Anderson 2013). As a consequence, the potential contribution of tourism to poverty reduction must be questioned (Chapter 6).

\section{No trade barriers}

Tourism is often considered an attractive development option because, unlike many other industries or sectors, it faces no trade barriers. In other words, it is not uncommon for individual countries or trading blocs, such as the European Union, to impose restrictions on imports such as tariffs or quotas in order to protect and support their internal markets. By contrast, international tourism suffers no such restrictions. In general, tourism-generating countries place no limits on how many of their citizens may travel overseas, where they go, how often and how much they may spend although there are exceptions, such as the long-standing ban on Americans flying directly from the USA to Cuba. This ban was lifted during the Obama era, only to be partly reinstated in 2017 by the Trump administration. Hence, by and large, destinations have free and equal access to international tourism markets and are able to exploit 'an export opportunity free of the usual trade limitations' (Jenkins 1991b, p. 84). They must still, however, operate in an increasingly competitive international market, and transport links and the extent of local tourism infrastructure may also serve to limit the growth of tourism at the destination.

\section{'Free' resources}

Compared to many other industries, tourism is considered to have relatively low start-up costs inasmuch as many of the resources that attract tourists, whether natural, such as mountains and beaches, or built heritage, already exist and thus are, in a simplistic sense, 'free'. Of course, they are not free as, inevitably, costs are incurred in their upkeep and protection and many argue that an economic value should be placed on their use and included as part of the price that tourists pay (Mihalič 2015). At the same time, substantial investment might be required in infrastructure and facilities to enable tourists to travel to and enjoy these resources. Nevertheless, tourism is often favoured as a development option given the preexistence of these basic resources. 


\section{Social and environmental benefits}

In addition to the above factors, the development of tourism offers a number of 'spin-off' benefits to the destination and the local community. For example, infrastructural, facility and amenity developments for tourism, from power supplies and transport infrastructure to restaurants, entertainment facilities and other services such as policing and health care are also of benefit to and utilized by the local community. At the same time, the destination may be improved for the local community by general environmental protection and enhancement schemes whilst specific policies, such as national park designation, provide additional environmental and recreational resources for local people. Moreover, tourism may also serve to strengthen or revitalize local cultural identity through stimulating cultural performances, the production of traditional arts and crafts or the organization of culturally based festivals.

There are, then, compelling reasons for the adoption of tourism as opposed to other industries or economic sectors as a catalyst of development. These are, for the most part, related specifically to the economic benefits that accrue from tourism; that is, as a global economic sector of significant scale and value - simply stated, as big business - tourism acts primarily as an engine of economic growth. However, as observed above, although once considered synonymous with economic growth, development has evolved into a much broader concept. Hence, in order to consider the relationship between tourism and development and, as is the intent of this book, to propose a research agenda to enhance understanding of that relationship, it is now necessary to review briefly what development 'is' and transformations in development theory.

\section{Development: definitions and processes}

The academic study of development first emerged in the $1950 \mathrm{os}$ as a branch of development economics and, subsequently, development studies as a discrete, albeit interdisciplinary, field of academic endeavour became established in the $1960 s$. Since then, it has evolved and transformed, addressing development from a variety of disciplinary and practical perspectives (Desai \& Potter 2013). According to Harriss (2005), however, the future direction of development studies remains uncertain, not least reflecting wider concerns and debates surrounding the validity of development itself as a global 'project' (Sidaway 2007). That is, since the 1990s, proponents of the so-called 'post-development' school have suggested that the notion of global development is flawed, unjust, has failed in its objectives and, hence, should be abandoned or replaced with an alternative approach (Rahnema 1997). Similarly, Payne and Phillips (2010, p.3) suggest that 'contemporary development studies, although still a sizeable academic enterprise in many Western countries, is at the same time an uncertain and under-confident discipline'. However, their solution to this impasse is to 'relocate the study of development squarely within the intellectual project of political economy and the diverse theoretical traditions associated with it' (Payne \& Phillips 2010, p. 181). 
It is not possible to consider these debates in detail here, although they are of undoubted relevance; that is, given the widespread support for and dependence upon tourism as a development strategy, it is logical to question that role from a critical perspective on development itself. Nevertheless, for the purposes of this chapter, two issues demand brief consideration: first, how development may be defined or thought of and, second, the evolution of development paradigms (for more detail, see Telfer 2015).

\section{Defining development}

An immediate challenge in considering development is that it is a concept that 'seems to defy definition' (Cowen \& Shenton 1996, p. 3). On the one hand, it is typically used to refer to a process of social change and, implicitly, 'betterment'; on the other hand, it may be seen as a philosophical concept alluding to a desirable future state or condition. Either way, however, a universal definition would appear to be optimistic and, hence, development should perhaps be considered in relation to the needs or aims of particular societies and the ways in which those societies seek to address their specific societal challenges (Hettne 2009). Nevertheless, it can broadly be thought of as the process and outcome of a specific kind of social change; as Goulet (1968, p. 388) puts it, development 'refers both to the destination of a journey and to the journey itself'.

That 'destination' has changed over time. The initial alignment of development with economic growth in the 1950 and early 1960 s referred to earlier in this chapter was soon challenged when it came to be recognized that in many countries, economic growth was not only failing to solve social and political problems but was also causing or exacerbating them. In particular, it was argued that, beyond overall economic growth, fundamental to development is solving the three problems of poverty, unemployment and inequality (problems that to varying extents still remain unresolved in both developed and developing countries). According to Seers (1969), even if just one of these has become more acute then, even if per capita income has grown significantly, development cannot be considered to have occurred.

To these three challenges Seers (1977) later added a fourth, namely, self-reliance. That is, in an era of increasing dependence emphasized by the 1970 oil crisis, the notion of self-determination also became fundamental to development. Putting it another way, the concept of freedom, later to be considered synonymous with development (Sen 1999), entered the equation; the path to development required freedom of choice for individual members of societies and freedom from servitude to ignorance, nature, other societies, beliefs and institutions (Sharpley 2015). Thus, development came to be seen as a broad concept embracing at least five dimensions (see Goulet 1992):

- an economic component - wealth creation and equitable access to resources

- a social component - improvements in health, housing, education and employment 
Table 1.3 Sustainable Development Goals

1 No poverty

2 Zero hunger

3 Good health and well-being

4 Quality education

5 Gender equality

6 Clean water and sanitation

7 Affordable and clean energy

8 Decent work and economic growth

9 Industry, innovation and infrastructure
10 Reduced inequalities

11 Sustainable cities and communities

12 Responsible production and consumption

13 Climate action

14 Life below water

15 Life on land

16 Peace, justice and strong institutions

17 Partnerships for the goals

Source: Adapted from UN 2017.

- a political dimension - assertion of human rights, appropriate political systems

- a cultural dimension - protection or affirmation of cultural identity and self-esteem

- the full-life paradigm - preservation and strengthening of a society's symbols, beliefs and meaning systems.

To these, perhaps, should be added an ecological component, reflecting not only the emergence of environmental sustainability as a fundamental parameter of contemporary approaches to development but also its centrality to the concept of sustainable tourism development which, as considered later in this chapter, has been a dominant theme in the tourism and development literature since the early 1990s. It is also notable that these components of development are broadly reflected in the current Sustainable Development Goals (see Table 1.3), whilst the most widely accepted measure of development is the annual UN Development Programme (UNDP) Human Development Index which ranks countries according to a variety of economic and social indicators.

To summarize, then, development may be considered to be essentially a social phenomenon focusing on the betterment of the human condition, or what a recently devised development index refers to as social progress: 'Social progress is the capacity of a society to meet the basic human needs of its citizens, establish the building blocks that allow citizens and communities to enhance and sustain the quality of their lives, and create the conditions for all individuals to reach their full potential' (Porter et al. 2013, p. 7). Putting it another way, development may be defined as the continuous and positive change in the economic, social, political and cultural dimensions of the human condition, guided by the principle of freedom of choice and limited by the capacity of the environment to sustain such change (Sharpley 2015, p.22). This is reflected in the UNDP's most recent definition of human development (UNDP 2010, p.22) as: 'the expansion of people's freedoms to live long, healthy and creative lives; to advance other goals they have reason to value; and to engage actively in shaping development equitably and sustainably on a shared planet'. 


\section{Development paradigms}

Just as definitions and understandings of development have evolved over the last half century, so too have development paradigms or theories of development (that is, a combination of the ideological ends of development and the strategic means of achieving them). These are addressed at length in the literature (for example, Peet \& Hartwick 2015) although, as with the preceding discussion of definitions, an overview of key points will suffice for the purpose of this chapter. That is, it is important to consider the means by which tourism may contribute to development and, in particular, whether contemporary paradigms are applicable to the specific context of tourism (Telfer 2015).

Broadly speaking, development paradigms have evolved along a trajectory from top-down economic growth-based approaches to a broader focus on enhancing human well-being with an emphasis on endogenous, bottom-up development. For some, this evolution is evident in a journey from traditional modernization theory through to sustainable development, the latter still occupying a dominant position in development policies in general and tourism development policies in particular; for others, that journey has continued into human development and beyond into global development. Table 1.4 summarizes a chronology of development paradigms, although it should be noted that emerging paradigms have not replaced but rather supplement preceding ones which remain of relevance to particular contexts. For example, in some instances, tourism and its potential developmental contribution may be best explained by modernization theory; in others, such as pro-poor tourism interventionist policies, human development is more in evidence whilst, as noted earlier, CBT is most closely aligned to alternative development. Each paradigm is now explained briefly.

\section{Modernization}

Modernization theory combines the notion that all societies follow an inevitable evolutionary path from traditional to economic, political and social modernity with the belief that, once a particular point along that path has been reached - the so-called 'take-off' stage (Rostow 1967) - then development based upon economic growth can occur. Significantly, that development may be stimulated by the introduction of a 'growth pole' (that is, an industry or economic sector) from which 'growth impulses' diffuse throughout the region. There is, then, a direct corollary with tourism. A tourist resort may act as a growth pole, the growth impulses being the backward linkages referred to earlier in this chapter. Cyprus (Sharpley 2003) and Mexico (Clancy 2001) are examples of the application of tourism-related modernization theory.

\section{Dependency}

Dependency theory, which emerged in the 1960 s as a critique of the modernization paradigm, is essentially a neo-Marxist explanation of why development does 
Table 1.4 The evolution of development theory

\begin{tabular}{|c|c|c|}
\hline Period & Development paradigm & Theoretical perspectives \\
\hline 1950s-1960s & Modernization & $\begin{array}{l}\text { Stages of growth } \\
\text { Diffusion: growth impulses/trickle-down effect }\end{array}$ \\
\hline 1950s-1970s & Dependency & $\begin{array}{l}\text { Neo-colonialism: underdevelopment caused by } \\
\text { exploitation by developed countries } \\
\text { Dualism: poverty functional to global economic } \\
\text { growth } \\
\text { Structuralism: domestic markets, state involvement }\end{array}$ \\
\hline $\begin{array}{l}\text { mid-1970s- } \\
\text { 1980s }\end{array}$ & Economic neo-liberalism & $\begin{array}{l}\text { Free market: free competitive markets/privatization } \\
\text { Structural adjustment: competitive exports/market } \\
\text { forces } \\
\text { One world: new world financial systems }\end{array}$ \\
\hline $\begin{array}{l}\text { 1970s-early } \\
1980 \text { s }\end{array}$ & Alternative development & $\begin{array}{l}\text { Basic needs: focus on food, housing, education, } \\
\text { health } \\
\text { Grassroots: people-centred development } \\
\text { Gender: gender relations/empowerment } \\
\text { Sustainable development: environmental } \\
\text { management }\end{array}$ \\
\hline $\begin{array}{l}\text { Late 1980s- } \\
\text { early 1990s }\end{array}$ & $\begin{array}{l}\text { The impasse and post- } \\
\text { development }\end{array}$ & $\begin{array}{l}\text { Post-modern critique of metanarratives of } \\
\text { development discourse; pluralistic approaches } \\
\text { that value local knowledge and solutions }\end{array}$ \\
\hline $1990 s-2000 s$ & Human development & $\begin{array}{l}\text { Human development: freedom, democratic and } \\
\text { human rights, poverty reduction } \\
\text { State-led development } \\
\text { Focus on civil society and social capital } \\
\text { Transnational social movements: environment, } \\
\text { peace, etc. } \\
\text { Culture: different world views are accommodated } \\
\text { Human security; challenging the 'failed state' }\end{array}$ \\
\hline $\begin{array}{l}\text { 2000s and } \\
2010 \text { s }\end{array}$ & Global development & $\begin{array}{l}\text { Focus on enhancing global international } \\
\text { relations and governance through yet to be built } \\
\text { supranational political institutions }\end{array}$ \\
\hline
\end{tabular}

Source: $\quad$ Adapted from Telfer 2015, pp. 36-7; also Telfer \& Sharpley 2016, p. 16.

not occur. Its fundamental premise is that a country's underdevelopment reflects the external and internal political, economic and institutional structures that keep it in a dependent position relative to developed countries. More precisely, dependency theory argues that global political and economic relations are such that wealthier, more powerful Western nations are able to exploit weaker, peripheral nations (often mirroring earlier colonial ties), thereby limiting developmental 
opportunities within developing countries. Various theoretical perspectives on dependency theory exist although tourism has long been considered a manifestation of the paradigm (Bastin 1984; Britton 1982; Nash 1989).

\section{Economic neo-liberalism}

The 1980 s Reagan-Thatcher era was characterized by a return to the politics of economic liberalism. In the context of international development, this was manifested in policies that sought to counter existing excessive state intervention, promoting instead development lending contingent on market liberalization, the privatization of state enterprises and the overall reduction in the role of the state. So-called Structural Adjustment Lending Programmes became popular yet soon became widely discredited for enhancing rather than solving development challenges (Harrigan \& Mosley 1991). Consequently, these were superseded by Poverty Reduction Strategy Papers, which encouraged local participation in development strategy, though these have also proved to be unsuccessful (Lazarus 2008).

\section{Alternative development}

The alternative development paradigm offers, literally, an alternative to the preceding top-down interventionist approaches to development. Instead, it adopts a resource-based, bottom-up approach that focuses primarily on human and environmental concerns, based on the fundamental tenet that development should be endogenous. In other words, the development process should start within and be guided by the needs of each society rather than being externally imposed. Hence, alternative development also emphasizes the importance of satisfying basic needs and of encouraging self-reliance (Galtung 1986). Significantly, it underpinned the subsequent emergence of sustainable development, a concept that continues to dominate global development policy, whilst as discussed earlier in this chapter, the 1980 os concept of 'alternative tourism' not coincidentally adapted the principles of alternative development to the specific context of tourism.

\section{The impasse and post-development}

The 1980 os were considered by some to be a lost decade of development. Not only had the developmental gap between rich and poor nations failed to diminish but also the collapse of socialism as a political system, the inherently oxymoronic nature of sustainable development, the diminishing role of the nation-state in an increasingly globalized world, as well as the perceived failure of preceding development policies (including sustainable development) led to claims that the concept of development as a global project had not worked. Consequently, it was also suggested by some that development thought had reached an impasse, hence the emergence of the 'post-development' school, an eclectic collection of approaches to development that, broadly, favoured traditional, non-modern/Western philosophies and cultures and emphasized local engagement, community involvement and autonomy from the state in development processes. Within the context of tourism, 
however, development policies continued to be framed by the sustainable development paradigm.

\section{Human development}

As discussed in the preceding section, the concept or definition of development has evolved over time, most recently being considered the process and objective of improving human well-being. This is reflected in the human development paradigm which, rather than promoting a specific 'blueprint' of development, embraces a variety of approaches and practices unified by a focus on improving the human condition. In addition to the adoption of measures such as the UNDP's annual Human Development Index with a focus on indicators such as life expectancy, education and income, issues including human rights, democracy and good governance, debt cancellation and poverty reduction are also embraced by human development. The UN's Sustainable Development Goals (see Table 1.3) are evidence of the centrality of human well-being in development, each goal arguably requiring different policies and processes for its achievement. Within the tourism context, more recent approaches to and forms of tourism, such as pro-poor tourism (Harrison 2008; Scheyvens 2015) and volunteer tourism (Wearing \& McGehee 2013) are examples of a focus on human development although, in the context of tourism development globally, these arguably remain on the margins.

\section{Global development}

According to Held (2010, p. 220):

Today, there is a newfound recognition that global problems cannot be solved by any one nation-state acting alone, nor by states just fighting their corner in regional blocs. What is required is collective and collaborative action - something the states of the world have not been good at, and which they need to reconsider and advance if the most pressing issues are to be adequately tackled.

In short, despite recognition of the right of nations to individually address their development challenges, in an increasingly interconnected globalized world that faces global problems, the establishment of new supranational political organizations is clearly necessary. To some extent, such as in the context of climate change, this is already occurring; within tourism in particular, however, despite the existence of the UNWTO and other bodies committed to enhancing international co-operation in tourism, it has long been recognized that, as a fragmented and multi-sectoral industry, global consensus on policies and processes is unlikely to be achieved (McKercher 1993).

Overall, then, it is evident that over time, both the processes and objectives of development have evolved from relatively simplistic economic growth models through the more complex notion of sustainable development to a more specific 
focus on human development. It is also evident that, in some respects, tourism policies and processes in particular have reflected this evolution. Nevertheless, given that tourism, as observed at the outset of this chapter, has long been considered a vehicle of development, the next task is to explore the various approaches proposed within the literature for realizing this potential; that is, for establishing an effective link between tourism and development. This will provide the basis for then outlining future research needs within the field of tourism and development.

\section{Tourism and development: conceptual approaches}

As observed earlier, the academic study of and research into tourism and development has advanced through a number of stages, the last two decades in particular being characterized by more theoretically informed, multi-disciplinary perspectives on the relationship between tourism and development. As a consequence, a variety of conceptual approaches have been proposed in the literature - and to an extent adopted in practice - that seek to enhance both the benefits accruing from tourism to the local community and an understanding of how such benefits might be transferred. Most of these approaches have attracted significant attention and have become discrete themes in tourism studies in their own right, some becoming the focus of a substantial literature. In particular, the concept of sustainable tourism development has not only spawned innumerable books, chapters and articles and special issues but, for more than 20 years, also enjoyed its own dedicated journal (Journal of Sustainable Tourism), as has also the concept of ecotourism.

The purpose here is to present a brief overview of each theme, in so doing providing an overall 'flavour' of extant research in tourism and development and highlighting key questions or areas of contention that arguably would justify further research.

\section{Tourism and development: economic perspectives}

Tourism is primarily an economic phenomenon. That is, although it is manifested in the movement of significant volumes of people within and across national borders, it is the spending by those people on the goods and services that collectively comprise the tourist product or experience that endows tourism with significance as a catalyst of development in destination areas. In other words, it is primarily in the economic benefits of tourism, as reviewed earlier in this chapter, that the attraction of tourism lies, whether as a stimulus of economic growth in general or as a means of achieving specific objectives, such as enhancing foreign exchange earnings or poverty reduction, in particular. It then follows that, as the primary developmental outcomes of tourism are economic, subsequent social development may follow, though not inevitably. That is, at the destinational level, a variety of factors such as the nature of tourism development and other political and socioeconomic variables may determine the extent to which tourism contributes to wider development. 
Importantly, however, even positive economic benefits cannot be assumed as an inevitable outcome of tourism development; indeed, as Mihalič (2015, p. 80) observes, destinations may often exaggerate or take for granted the potential contribution of tourism to economic growth whilst overlooking the economic costs that may limit the benefits that accrue. Such economic costs (and benefits) have long been considered in the literature, both in general texts exploring the economics of tourism (for example, Bull 1995; Dwyer \& Forsyth 2006; Tribe 2005; Wall \& Mathieson 2006) and more specific studies of, for example, backward economic linkages (Telfer \& Wall 200o), tourism multipliers (Archer 1982), supply chains (Ashley \& Haysom 2008; Zhang et al. 2009) and employment generation (Farver 1984; Leiper 1999). Equally, not only has knowledge and understanding of tourism's economic contribution become more detailed and nuanced through, for example, the development of satellite accounting (Smeral 2006) and, in practice, models for the more realistic measurement of tourism spending, but also research into tourism's economic potential, taking into account factors such as the structure and maturity of the local destination economy, has become more sophisticated. Indeed, in the context of this book, it could be argued that, from an economics disciplinary perspective, the economic dimension of tourism and development is well understood, in particular at the level of individual destinations. Where research remains necessary, however, is in the ways in which the translation of the economic contribution of tourism into non-economic developmental benefits (for example, greater equity within and between societies) can be optimized or, indeed, if there are alternative, non-economic parameters by which the success (or failure) of tourism as an agent of development might be better measured.

\section{Alternative tourism and its derivatives}

Alternative tourism emerged, as observed by Cohen $(1987$, p. 13) in an early critique of the concept, as 'a fashionable idea among those ... dissatisfied with the nature of mass tourism'. By definition, it was proposed by its early proponents (for example, Holden 1984) in response to the perceived negative impacts of mass tourism development; that is, as an alternative to mass tourism. Its foundations, therefore, were to be found in the growing concern over the consequences of the rapid and seemingly uncontrolled growth and development of tourism from the 1960 on onwards, perhaps best epitomized not only in the rapid spread of large-scale homogenous resorts along the Spanish 'costas' but also in the annual mass migration of tourists to the sun on cheap package holidays. Indeed, as Cohen (1987) noted, alternative tourism is as much about alternative tourists seeking more individualistic, non-commoditized experiences as it is about planning and managing tourism development.

Alternative tourism, then, is essentially an umbrella term that refers to an approach to tourism supply and demand that is distinctive from (or the opposite to) mass tourism. Hence, an enormous variety of types of tourism, such as green tourism, nature tourism, adventure tourism, responsible tourism and, of course, ecotourism, can be thought of as derivatives of the concept of alternative tourism, yet all share a number of characteristics, as summarized in Table 1.5 . 
Table 1.5 Characteristics of mass versus alternative tourism

Conventional mass tourism

General features

Rapid development

Maximizes

Socially/environmentally inconsiderate

Uncontrolled

Short term

Sectoral

Remote control

Development strategies

Development without planning

Project-led schemes

Tourism development everywhere

Concentration on 'honeypots'

New building

Development by outsiders

Employees imported

Urban architecture

\section{Tourist behaviour}

Large groups

Fixed programme

Little time

'Sights'

Imported lifestyle

Comfortable/passive

Loud

Shopping
Alternative forms of tourism

Slow development

Optimizes

Socially/environmentally considerate

Controlled

Long term

Holistic

Local control

First plan, then develop

Concept-led schemes

Development in suitable places

Pressures and benefits diffused

Re-use of existing building

Local developers

Local employment utilized

Vernacular architecture

Singles, families, friends

Spontaneous decisions

Much time

'Experiences'

Local lifestyle

Demanding/active

Quiet

Bring presents

Source: Telfer \& Sharpley 2016, p. 57, adapted from Lane 1990 and Butler 1990.

Undoubtedly, many examples can be found of such alternative tourism developments (and tourists) in practice which may bring fewer negative consequences and greater benefit to local communities. However, this may not always be the case; many of the criticisms raised by Cohen in 1987 and subsequently by others remain current. In a practical sense, negative impacts may still be keenly felt whilst the implicit idealism of the concept and its condemnation of mass tourism not only overlooks the potential for alternative developments to become mainstream but also the fact that, as they are by definition small and local, so too are the benefits that accrue from alternative tourism. In other words, in many instances conventional mass tourism may bring greater net benefits to a destination whilst, as recently suggested (Harrison \& Sharpley 2017), alternative tourism might be more realistically considered a sub-category of the contemporary global phenomenon that is mass tourism. 


\section{Community-based tourism}

As a specific manifestation of alternative tourism development, a community-based approach to tourism was first proposed by Murphy $(1983,1985)$. Since then, it has attracted support and criticism in equal measure (Blackstock 2005; Joppe 1996; Scheyvens 2002; Tosun 2000), yet remains not only a popular focus of academic attention but also a highly contested concept (Jamal \& Dredge 2016).

In a sense, all forms of tourism development are concerned with bringing benefits to destination communities; as stated at the outset of this chapter, in principle this is the fundamental purpose of tourism although, in reality, such benefits may often be coincidental to the more pragmatic pursuit of tourism as a business. CBT, however, is a specific approach that seeks to enhance the developmental benefits of tourism through maintaining, to varying degrees, the local community's involvement in tourism. In practice, CBT may take many forms and communities may benefit from numerous kinds of association with external agencies (Simpson 2007) but, for many commentators, the local community should not only be involved in the planning of tourism but also have ownership of it, managing it on a day-to-day basis and sharing its benefits (Telfer \& Sharpley 2016, pp.192-8). Hence, CBT is, essentially, a means of empowering communities (Campbell \& Vainio-Mattila 2003; Scheyvens 2002), supporting local social development through tourism that meets local needs, respects local culture and traditions and supports environmental conservation. As such, it can be considered the counterpoint to large-scale resort developments controlled and owned by 'outside' organizations on which the local community become dependent for income and employment.

Inevitably, perhaps, much of the research explores or proposes ways in which CBT might be implemented, typically within conceptual frameworks of differing levels and types of community involvement and participation, such as Arnstein's (1969) and Pretty's (1995) widely cited models. Equally, issues surrounding collaboration and partnership are of relevance, particularly when a broader definition of community is applied (Bramwell \& Lane 2000). Overall, however, studies demonstrate that, in practice, not only is the concept of CBT widely interpreted but also that, often, it may be less successful than envisaged in bringing benefits to local communities (Goodwin \& Santilli 2009). Hence, there appears to be a mismatch between the continuing support for and promotion of the concept of CBT and its viability as a means of enhancing the developmental benefits to destination communities. This, in turn, points to the need for objective empirical research that considers the circumstances under which CBT may represent a realistic approach and how it may be achieved.

\section{Sustainable tourism development}

Sustainable tourism development has dominated research into tourism and development since the early 1990s, both as a concept in its own right and as a context for justifying and exploring more specific forms of tourism development. At the 
same time, it has remained the objective of tourism planning and management in practice; the UNWTO is committed to the concept, suggesting that 'sustainable tourism development guidelines and management practices are applicable to all forms of tourism in all types of destinations, including mass tourism and the various niche tourism segments' (UNWTO 2018), whilst destinations, industry sectors and other organizations actively seek to encourage the sustainable development of tourism. Moreover, 2017 was designated as the UN's International Year of Sustainable Tourism for Development.

Despite the widespread support for sustainable tourism development, however, debate continues to surround its viability in practice, reflecting, perhaps, longexpressed criticisms of its parental paradigm, sustainable development (for example, Redclift 1987). Indeed, given the more recent emphasis on human development within development circles (see Table 1.4), sustainable tourism development might arguably be considered to be anachronistic. While the arguments are many and sometimes complex, for present purposes a number of observations can be made (Sharpley 2009). First, a definitional distinction exists between sustainable tourism - a parochial emphasis on the sustainability of tourism itself (Hunter 1995) - and sustainable tourism development, the focus of which is on the achievement of sustainable development through tourism (Cronin 1990). The former (sustainability) is a prerequisite for any economic activity or business and is, unsurprisingly, the concern of much of the research, whereas the latter remains, perhaps, an idealistic (and contested) objective. Second and related, sustainable tourism development was considered from the outset as an alternative to mass tourism (Pigram 1990), a dichotomy that persists, not least in many sets of guidelines for sustainable tourism development. Hence, attention has primarily been focused on the nature of tourism itself rather than on its developmental outcomes (although specific approaches, such as pro-poor tourism as discussed below, go some way to addressing this limitation). Third, it has been demonstrated that, as a social and economic phenomenon, tourism cannot be mapped on to the principles and objectives of sustainable development (Sharpley 200o); specifically, the fundamental principles of futurity, equity and an holistic perspective cannot be met by tourism. And fourth, an often overlooked fact is that, as an activity involving primarily fossil fuel-dependent travel, tourism is inherently environmentally unsustainable (Høyer 200o). Hence, although there is clearly a need to explore ways of enhancing the sustainability of tourism itself, the time has perhaps come to draw a line under the concept of sustainable tourism development.

\section{Pro-poor tourism}

Whilst tourism has long been considered a catalyst of development in general, it is only relatively recently that tourism's potential to contribute to the alleviation of poverty in particular has attracted increasing interest. Indeed, it was only around the start of the new millennium that policies and projects targeting poverty reduction through tourism were first proposed, most notably through the work of the now defunct Pro-Poor Tourism Partnership funded initially by the UK's 
Department for International Development. The World Tourism Organization launched its Sustainable Tourism - Eliminating Poverty Programme (ST-EP) at the World Summit on Sustainable Development in Johannesburg in 2002 (see http:// step.unwto.org/content/st-ep-initiative-1) and only subsequently did academic attention turn to what is generally referred to as pro-poor tourism. Hence, it was in developmental circles that the notion of poverty reduction through tourism first emerged, the mantle subsequently being taken over by academics (Scheyvens 2015) and, since then, a burgeoning literature on the subject has evolved (for example, Ashley \& Mitchell 2010; Blake et al. 2008; Holden 2013).

As discussed later in this book (Chapter 6) as well as elsewhere (Harrison 2008), pro-poor tourism is not a specific type of tourism; any form of tourism, including mass tourism, might be pro-poor. Rather, it is an approach to tourism that seeks to provide the poor or those excluded from the tourism sector access to tourist markets, in so doing offering them the opportunity to earn income through tourism. The UNWTO's ST-EP programme, referred to above, proposes seven different strategies for engaging the poor in tourism, from employment in tourism enterprises to targeted/philanthropic schemes (see below), whilst there are examples of successful pro-poor tourism projects in practice. However, as essentially interventionist schemes (it is market forces that typically exclude the poor) dependent on funding and, usually, non-governmental organization (NGO) support, their longerterm viability is often questioned, as is the overall concept of pro-poor tourism (Harrison 2008).

\section{Tourism planning and governance}

If tourism is to contribute effectively to the wider socio-economic development of destinations or, indeed, if simply the economic benefits of tourism are to be optimized, appropriate planning and management is, inevitably, required. Put differently, if tourism is to meet its developmental objectives, then effective planning is a prerequisite; it should, in principle, establish what those objectives are and, within the context of available resources and opportunities, not only set out a path for the achievement of those objectives but also propose mechanisms for measuring the extent to which they have been achieved.

It is not surprising, therefore, that much of the literature is concerned, either directly or indirectly, with tourism planning and governance. Numerous texts explore the topic in detail, either from a 'pure' planning perspective (for example, Gunn \& Var 2002; Hall 2008; Inskeep 1991), from a strategic management perspective (Evans 2015) or from a public policy/governance perspective (Bramwell \& Lane 2012; Hall \& Jenkins 1995). Equally, the planning and management of specific forms of tourism, such as island tourism (Carlsen \& Butler 2011), urban tourism (Page \& Hall 2003) or tourism in protected areas (Eagles \& McCool 2002) have attracted significant attention, whilst a variety of approaches, such as community or participatory planning, as well as alternative perspectives (Burns 2004) are also considered. 
Importantly, however, the effective planning of tourism is not always (or perhaps even rarely) in evidence in practice (Ruhanen 2013). In other words, much of what is proposed in the extensive academic literature on tourism planning and governance is not reflected in the way in which tourism is often developed in reality. For example, although sustainable tourism development has remained the dominant tourism development paradigm in both academic and policy circles for more than two decades, a growth-focused 'industrial' model of tourism development persists (Pollock 2012). Equally, the so-called phenomenon of 'overtourism' is increasingly in evidence around the world, again pointing to the failure of planning or, perhaps, policies (Kerr 2003) in tourism development, as well as a disconnect between the academic study and the practice of tourism. There is, then, a pressing need for research into the planning and governance of tourism to identify not only the factors that have brought about planning failure (or success) but also to explore alternative means of establishing and implementing tourism policy and planning.

\section{Philanthropy: volunteer tourism}

Although the notion of 'responsible tourism' initially referred to an alternative approach to tourism planning in general (Haywood 1988; Wheeller 1991), it has reemerged as a more actor-centred approach demanding responsibility on the part of all stakeholders in the tourism system (see below). One specific form of tourism that arguably reflects such responsibility, at least on the part of tourists themselves, is so-called volunteer tourism (Wearing 2001) in which individuals pay to travel and engage in development-related voluntary activities, typically in developing countries, for all or part of their trip. Often, such activities involve conservation work although many volunteer tourists also seek to work on socio-economic projects including education, medical assistance or social care.

Of course, the concept of travelling overseas (and domestically) to work voluntarily is not new; as observed elsewhere (Sharpley 2018), organized international volunteering has existed since the mid-twentieth century, though usually involving individuals with identified skills for longer periods of time. In recent years, however, volunteer tourism has become a recognized and increasingly popular sector of the overall tourism market as, in particular, growing numbers of younger people, often as part of their 'gap year' either before or after attending university, join volunteering projects organized and sold by an also growing number of specialist organizations. At the same time, as Wearing and McGehee (2013) note, much of the academic research into the phenomenon, perhaps unsurprisingly, also emerged during this period. Initially, volunteer tourism was advocated as an effective means of contributing directly to local sustainable development, although soon a number of negative consequences came to be identified, such as the reinforcement of cultural stereotyping (Raymond \& Hall 2008; Simpson 2004) or highlighting inequality (Lyons et al. 2012; Sin 2010). The popularization of volunteer tourism as a commercial tourism product has also stimulated debates surrounding the altruistic or selfinterest motives of those participating in it, with many suggesting that it is no more than an ego-centric tourism experience (Daldeniz \& Hampton 2010) involving a 
self-therapeutic retreat from public policies and a diminution of political and moral agency (Butcher \& Smith 2015).

Interestingly, however, less attention has been paid to the benefits of volunteer tourism accruing to host communities (Lupoli et al. 2014); that is, it remains unclear to what extent volunteer tourism brings positive developmental benefits to destinations and host communities. Moreover, the relative benefits of volunteer tourism compared with other, often 'hidden' tourism-related philanthropy, such as the private establishment of charitable projects by tourists visiting developing countries, have yet to be explored.

\section{Responsible tourism: a 'moral' approach?}

As noted in the preceding section, the concept of responsible tourism first emerged in the late 1980 on and early 1990 s as a more environmentally and socially appropriate alternative to mass tourism development (Cooper \& Ozdil 1992; Harrison \& Husbands 1996). It referred to a more responsible approach (to destination environments and communities) in planning and managing tourism. In more recent years, however, it has re-emerged and, indeed, garnered significant support within some sectors of the tourism industry as an approach to tourism that emphasizes the requirement for all stakeholders, including tourism businesses and tourists themselves, to take responsibility for their roles and actions in tourism (Goodwin 2011). In practice, this has been evidenced in the promotion and adoption of principles for responsible tourism by (some) businesses and industry bodies alike, reflecting its alleged benefits as defined in the Cape Town Declaration on Responsible Tourism (ICRT 2010):

- minimizes negative economic, environmental, and social impacts;

- generates greater economic benefits for local people and enhances the wellbeing of host communities, improves working conditions and access to the industry; involves local people in decisions that affect their lives and life chances;

- makes positive contributions to the conservation of natural and cultural heritage, to the maintenance of the world's diversity;

- provides more enjoyable experiences for tourists through more meaningful connections with local people, and a greater understanding of local cultural, social and environmental issues;

- provides access for physically challenged people; and

- is culturally sensitive, engenders respect between tourists and hosts, and builds local pride and confidence.

As such, and as discussed by Harrison and Pratt in this book in their chapter on tourism and poverty, it may be considered a form of tourism-specific corporate social responsibility (CSR).

Interestingly, it has also been promoted as a tourism product - responsible travel with the focus very much on tourist experiences that are the antithesis to the organ- 
ized, mass form of travel (see www.responsibletravel.org). In other words, although its proponents suggest that responsible tourism should be the objective of all tourism businesses, all tourists and all destinations, its roots in alternative tourism remain.

Whilst it is difficult to argue against the principle of responsible tourism (as it is similarly difficult to argue against the principle of sustainable tourism development with which it might be considered synonymous), its viability in practice has long been criticized (Sharpley 2012). In particular, it is suggested that, despite surveys that suggest otherwise, tourists themselves are generally unlikely to adopt so-called responsible behaviour, whilst it also remains uncertain to what extent businesses across the tourism sector have adapted their practices to meet responsibility guidelines. That is, although a number of larger, higher-profile organizations support the concept of responsible tourism, significant doubts surround its more general adoption. Hence, further research is required to address the question: is responsible tourism a realistic objective, or is it simply an example of what has been described as the moralization (Butcher 2002) of tourism?

\section{Towards a research agenda: contributions to this book}

Recent academic critiques of tourism often bear more than a passing similarity to many of those first voiced in the 1970s. It can also be argued that the research agenda for tourism academics has not kept pace with the truly remarkable changes in forms of tourism and their perceived relationship to development over the last four decades. It is here that our contributors become especially relevant for, more or less explicitly, they address the research issues relating to modern tourism we have identified in the previous pages.

For Dianne Dredge, in Chapter 2, standard approaches to tourism policy making are driven by the private sector and are too narrowly based on neo-liberal notions of trickle-down economics and market self-regulation. Such tourism policies do not lead to poverty reduction and/or development, and benefit only the higher echelons of society (a claim further discussed in other chapters of this book). Instead, defining policy as a socially constructed, emergent process aimed at the redistribution of resources, involving the agency, inter alia, of both academics and policy makers, she advocates a tourism research agenda which recognizes an underlying structure of capitalist power relations. In such 'deep' research, nine themes are considered especially relevant: ideologies, public versus private interests, the redistribution of resources, diverse values, representation in policy making, issue identification, policy consequences, knowledge needs and a future orientation. They are the basis of her tourism research agenda, and help determine the appropriate policy questions and 'practical policy knowledge', a kind of 'to do' list as to how to go about researching the key issues.

How far Dredge's radical agenda will reduce the scepticism of policy makers towards academics, which she correctly identifies, is open to question. However, 
her insistence on the crucial role of the state in tourism development is echoed by Adu-Ampong in Chapter 3. His focus is specifically on governance, and he directs us to the state and other institutional actors and interest groups with key roles in the policy-making process as it pertains to tourism and development. As he notes, research into the political arena where tourism occurs has tended to emphasize the need to manage tourism firms and destinations, but this omits the wider context of tourism development. What is needed, instead, is (again) a wider political economy approach, where governance is conceptualized as the bringing together of a variety of actors to achieve some collective goal, and where the historical and current role of the state and its changing interaction with other major players on the tourism development stage is crucial.

In Chapter 4, Clausen examines the influence of another major tourism stakeholder, the NGO. Her contribution is worrying. She notes the power held by NGOs and international NGOs in sustainable tourism development, especially as fundraisers and implementing agencies. They increasingly participate in such apparently 'niche' areas as ecotourism, volunteer tourism, pro-poor, fair trade and celebrity tourism, all of which she describes, but the tourism projects in which they are involved, and the aims and objectives they espouse, are neither regularly monitored nor evaluated. Similarly, little attention is accorded to the ethical and political framework within which they operate. According to Clausen, research is urgently needed into such NGO activities, not only of Northern-based NGOs working across the NorthSouth divide, but also of those (of increasing importance) operating across countries within the South. She also recommends research into how NGOs intersect with the state and the market - in short, the manner they articulate with two other sets of major stakeholders in sustainable tourism development.

In Chapter 5, Scarth and Novelli highlight the most obvious tourism stakeholder of all - the tourist - and the extent travel(ler) philanthropy can contribute to development, especially in Sub-Saharan Africa. They note the growing importance of donations, in cash or kind, received directly from individuals or by or through tour operators, who may also operate their own programmes of CSR. Such highly 'moral' contributions, found across a wide range of holiday providers, can be an add-on feature of a vacation or even a central feature of the holiday experience, promoting a 'feel-good' factor for the tourist. However, as Scarth and Novelli argue, individual 'feel good' does not necessarily translate to 'do good' at the community level. Rather, such donations can lead to communal dependency on handouts, or corruption and, more generally, there is little empirical evidence of the development role of tour operators. Put simply, the circumstances of much tourist giving are unaccountable and lack transparency, and the consequences of travel(ler) philanthropy are unresearched and unknown.

Numerous claims have been made - and contested - concerning tourism's role in poverty alleviation. Harrison and Pratt, in Chapter 6, point to clear macro-economic evidence that international tourism does contribute to economic growth and poverty reduction (though they recognize it can also contribute to social inequality). It 
does so through the conventional capitalist activities of tourism enterprises, including mass tourism, or through smaller tourism enterprises that 'piggy back' on larger private-sector organizations. As also discussed in Chapters 4 and 5, poverty reduction can occur through tourism activities of NGOs that are targeted at the poor, and through private-sector CSR programmes. Finally, some small, non-profit (and sometimes indigenous) enterprises engage in tourism simply to meet basic needs. Harrison and Pratt argue that research should identify those kinds of tourism most effective in reducing poverty and, also, that comparative research is required on how other stakeholders can influence the distribution of tourism's benefits, including such community benefits as roads and electricity. We know tourism can reduce poverty; as yet, it is difficult to say precisely how, where and when.

Case studies sometimes clarify wider issues of tourism and development. That by Jamal, Budke and Barradas-Bribiesca in Chapter 7 , of development in La Cuadrilla, an Otomi community in Mexico, is informed by a 'hard' model of CBT, and situated within a 'One Health' understanding of sustainable development, where human, animal and environmental sub-systems are in balance. This perspective, clearly at odds with neo-liberal perceptions of 'development', is (implicitly) tested in their analysis of women's cooperatives, spearheading the move from a low-paid agricultural base to a more diversified, commoditized economy, based on the sale of traditional embroidery. While some traditional practices were in decline, considerable success was also reported: community engagement and civic learning increased, and women became individually and collectively more empowered, socially, economically and culturally. Inevitably, the short research period, small focus groups, unelaborated role of tourism and significant NGO involvement means results can only be indicative. However, such case studies can inform further research on how sustainable development can be more widely achieved.

In Chapter 8, Sharpley emphasizes the relationship of tourism consumption and development. Tourists attach changing cultural significance to the tourism 'product', which may influence their self-esteem, and he suggests three especially significant themes in research on the consumption of tourism. First, tourist motivation has been a major focus of tourism studies, though, he notes, they have been more conceptual than empirical. Second, there has been extensive research on the demand for tourist experience - the pushes, pulls and conditioning factors - and, finally, there are tourist roles and experiences, which can be theorized at length (for example, the ubiquitous topic of authenticity) or considered major areas of empirical study. All such aspects of tourism require further research. If tourism is to be planned and managed, present and future international trends must be understood, including their underlying demographic causes. Also, despite much rhetoric on 'responsible' tourism, we urgently need research on values espoused by tourists, including the extent to which they can be active and 'responsible' contributors to 'development'.

Moving to the macro level, in Chapter 9, Aramberri traces the historical realignment or 'unbundling' of global relations of production, consumption and 
communication, in two great movements: first, since the 1800 , from pre-industrial to industrial, capitalist production and the emergence of powerful $\mathrm{G}_{7}$ industrial nations and, second, the 1990 s outsourcing of information and communication technologies to an additional Industrial Six nations, notably, China, India, Korea, Indonesia, Thailand and Poland. Into this mix comes post-1950s mass tourism, operating an extensive global value chain for travel and hospitality services. The process is illustrated by reference to mass tourism in Majorca (dominated by powerful West European tour operators in a low-wage Spanish economy), lowcost carriers, first in the West and later in South and Southeast Asia and, finally, the growth of nautical tourism, notably in Croatia, initially among an elite but increasingly - with the development of yacht charters - for the aspiring international middle class. Such patterns of tourism clearly relate to 'development', in that they radically increase the GDP of international tourist destinations, but point to challenges facing the nature of employment in tourism, an issue also highlighted in Chapter 10 as well as raising important questions about not only the potential of non-economic contributions to development through tourism but also the ability of destinations to manage the nature and direction of tourism development at the destinational level.

Mooney and Baum direct attention to another, much neglected category of stakeholders, the underpaid, undervalued, and underresearched workforce in tourism and (especially) hospitality. In Chapter 10, they describe at length the current state of research in a wide range of areas, notably critical hospitality studies, human resource management, strategic human resource approaches, peripheral tourism workforce studies, labour geographies and diversity management in tourism and indigenous tourism. Included in their discussion are, inter alia, links between hospitality and sex work, the management orientation of hospitality research, the poor application of human resource principles, short termism and resistance to change in the hospitality and tourism sector, and the multi-disciplinarity of much hospitality research which, nevertheless, has failed to engage with diversity - including indigenous employees - in the workforce. Concluding, Mooney and Baum advocate a macro-level research agenda level that prioritizes ethical policies for a less exploited and more empowered workforce and, at the management level, one that focuses on the possible organizational and community benefits from a similarly orientated Sustainable Human Resource Management model.

Finally and fittingly, in Chapter 11, Telfer focuses on tourism's importance in developed countries. After noting how research questions emerge from prevailing development paradigms, he argues that, since the 1970s, developed countries have been characterized by increased inequality. Nevertheless, tourism, especially domestic and regional tourism, has promoted economic growth, though more research is needed on why and when successes have been achieved. In addition to theory-led research questions, Telfer isolates several major topics requiring urgent research:

- gentrification, overtourism and the emerging sharing economy (for example, Airbnb and Uber), which bring undoubted benefits to individuals but also create 
problems in the community (for example, inflated accommodation costs);

- the connection of tourism growth, increased carbon emissions and low-cost carriers, together forming another example of overtourism;

- as also indicated by Mooney and Baum, the underresearched, undervalued and underregulated employment structure of hospitality and tourism, especially when threatened by technological innovation; and

- the potential for tourism to reduce poverty and promote inclusive growth, and the role played by government policies in redistributing the financial benefits brought by tourism.

From their very different perspectives, contributors to the following chapters offer a rich vein of potential research into tourism and its relationship to development. Some point to (what they consider to be) the 'big picture' of tourism in a global economy dominated by neo-liberalism and elsewhere we, too, have recognized the systemic global interconnections that link tourism in developing and developed societies (Harrison \& Sharpley 2017). Others focus on social and economic institutions and stakeholders in tourism, including NGOs, the state, women, workers in hospitality and tourism and the tourists themselves. Most also ask how far tourism does (or can) reduce poverty and bring about inclusive growth. This is perhaps the biggest question of all, which can be asked of any kind of tourism - mass or 'alternative' - in any kind of society - developing or developed - and while at present there is much rhetoric on the topic, there is still very little evidence. We can indeed examine growth rates and gross national product, but we must also ask what is happening within economies, societies and regions. Put differently, the size of the cake is important, but so, too, is how it is divided, according to what criteria and by whom.

\section{References}

Anderson, W. (2013), 'Leakages in the tourism systems: Case of Zanzibar', Tourism Review, 68(1), $62-76$.

Archer, B. (1982), 'The value of multipliers and their policy implications', Tourism Management, $3(4)$, 236-41.

Arnstein, S. (1969), 'A ladder of citizen participation', Journal of the American Institute of Planners, 35(4), 216-24.

Ashley, C. and Haysom, G. (2008), 'The development impacts of tourism supply chains: Increasing impact on poverty and decreasing our ignorance', in A. Spenceley (ed.) Responsible Tourism: Critical Issues for Conservation and Development, Abingdon: Earthscan, pp. 129-56.

Ashley, C. and Mitchell, J. (2010), Tourism and Poverty Reduction: Pathways to Prosperity, London: Earthscan.

Bastin, R. (1984), 'Small island tourism: Development or dependency?', Development Policy Review, 2(1), 79-90.

Bigano, A., Hamilton, J.M., Lau, M., Tol, R.S. and Zhou, Y. (2007), 'A global database of domestic and international tourist numbers at national and subnational level', International Journal of Tourism Research, 9(3), 147-74.

Blackstock, K. (2005), 'A critical look at community-based tourism', Community Development Journal, 40(1), 39-49. 
Blake, A., Arbache, J., Sinclair, M.T. and Teles, V. (2008), 'Tourism and poverty relief', Annals of Tourism Research, 35(1), 107-26.

Bramwell, B. and Lane, B. (eds) (200o), Tourism Collaboration and Partnerships: Politics, Practice and Sustainability, Clevedon: Channel View Publications.

Bramwell, B. and Lane, B. (eds) (2012), Tourism Governance: Critical Perspectives on Governance and Sustainability, Abingdon: Routledge.

Britton, S. (1982), 'The political economy of tourism in the Third World', Annals of Tourism Research, 9(3), 331-58.

Brohman, J. (1996), 'New directions in tourism for the Third World', Annals of Tourism Research, 23(1), 48-70.

Brown, F. (1998), Tourism Reassessed: Blight or Blessing? Oxford: Butterworth Heinemann.

Bull, A. (1995), The Economics of Travel and Tourism, 2nd edn, Melbourne: Longman.

Burns, P. (2004), 'Tourism planning: A third way?', Annals of Tourism Research, 31(1), 24-43.

Butcher, J. (2002), The Moralisation of Tourism: Sun, Sand . . and Saving the World? London: Routledge.

Butcher, J. and Smith, P. (2015), Volunteer Tourism: The Lifestyle Politics of International Development, Abingdon: Routledge.

Butler, R. (1990), 'Alternative tourism: Pious hope or trojan horse?', Journal of Travel Research, 28(3), $40-5$.

Campbell, L. and Vainio-Mattila, A. (2003), 'Participatory development and community-based conservation: Opportunities missed for lessons learned?', Human Ecology, 31(3), 417-37.

Carlsen, J. and Butler, R. (eds) (2011), Island Tourism: Sustainable Perspectives, Wallingford: CABI.

Clancy, M. (2001), Exporting Paradise: Tourism and Development in Mexico, Bingley: Emerald Group.

Cohen, E. (1987), 'Alternative tourism: A critique', Tourism Recreation Research, 12(2), 13-18.

Cooper, C. and Ozdil, I. (1992), 'From mass to responsible tourism: The Turkish experience', Tourism Management, 13(4), 377-86.

Costa, C., Panyik, E. and Buhalis, D. (eds) (2013), Trends in European Tourism Planning and Organisation, Bristol: Channel View Publications.

Cowen, M. and Shenton, R. (1996), Doctrines of Development, London: Routledge.

Cronin, L. (1990), 'A strategy for tourism and sustainable developments', World Leisure and Recreation, 32(3), 12-18.

Daldeniz, B. and Hampton, M. (2010), Charity-Based Voluntourism versus Lifestyle Voluntourism: Evidence from Nicaragua and Malaysia (working paper 211), Canterbury: Kent Business School.

de Janvry, A. and Sadoulet, E. (2016), Development Economics: Theory and Practice, Abingdon: Routledge. de Kadt, E. (1979), Tourism: Passport to Development? New York: Oxford University Press.

Desai, V. and Potter, R. (2013), The Companion to Development Studies, 2nd edn, Abingdon: Routledge. Diamond, J. (1977), 'Tourism's role in economic development: The case reexamined', Economic Development and Cultural Change, 25(3), 539-53.

Dwyer, L. and Forsyth, P. (2006), International Handbook on the Economics of Tourism, Cheltenham, UK and Northampton, MA, USA: Edward Elgar Publishing.

Eagles, P. and McCool, S. (2002), Tourism in National Parks and Protected Areas: Planning and Management, Wallingford: CABI.

EU (n.d.), Overview of EU Tourism Policy, European Commission. Accessed 2 January 2018 at http:// ec.europa.eu/growth/sectors/tourism/policy-overview_en

Evans, N. (2015), Strategic Management for Tourism, Hospitality and Events, 2nd edn, Abingdon: Routledge.

Farver, J. (1984), 'Tourism and employment in the Gambia', Annals of Tourism Research, 11(2), $249-65$.

Freitag, T. (1994), 'Enclave tourism development: For whom the benefits roll?', Annals of Tourism Research, $21(3), 538-54$.

Galtung, J. (1986), 'Towards a new economics: On the theory and practice of self-reliance', in P. Ekins (ed.) The Living Economy: A New Economy in the Making, London: Routledge, pp. 97-109. 
Gannon, A. (1994), 'Rural tourism as a factor in rural community economic development for economies in transition', Journal of Sustainable Tourism, 2(1-2), 51-6o.

Goodwin, H. (2011), Taking Responsibility for Tourism, Oxford: Goodfellow Publishers.

Goodwin, H. and Santilli, R. (2009), Community Tourism: A Success? ICRT Occasional Paper No. 11. Accessed 28 January 2018 at www.haroldgoodwin.info/uploads/CBTaSuccessPubpdf.pdf

Goulet, D. (1968), 'On the goals of development', Cross Currents, 18, 387-405.

Goulet, D. (1992), 'Participation in development: New avenues', World Development, 17(2), 165-78.

Gunn, C. and Var, T. (2002), Tourism Planning: Basics, Concepts, Cases, London: Routledge.

Hall, C.M. (2008), Tourism Planning: Policies, Processes and Relationships, Harlow: Pearson Education.

Hall, C.M. and Jenkins, J. (1995), Tourism and Public Policy, London: Thomson.

Harrigan, J. and Mosley, P. (1991), 'Evaluating the impact of World Bank structural adjustment lending', Journal of Development Studies, 27(3), 63-94.

Harrison, D. (ed.) (1992), Tourism and the Less Developed Countries, London: Belhaven Press.

Harrison, D. (2001), 'Islands, image and tourism', Tourism Recreation Research, 26(3), 9-14.

Harrison, D. (2008), 'Pro-poor tourism: A critique', Third World Quarterly, 29(5), 851-68.

Harrison, D. (2016), 'Looking East but learning from the West? Mass tourism and emerging nations', Asian Journal of Tourism Research, 1(2), 1-26.

Harrison, D. and Prasad, B. (2013), 'The contribution of tourism to the development of Fiji and other Pacific island countries', in C.A. Tisdall (ed.) Handbook of Tourism Economics: Analysis, New Applications and Case Studies, Singapore: World Scientific Publishing, pp. 741-6o.

Harrison, D. and Sharpley, R. (2017), 'Introduction: Mass tourism in a small world', in D. Harrison and R. Sharpley (eds) Mass Tourism in a Small World, Wallingford: CABI, pp. 1-14.

Harrison, L. and Husbands, W. (1996), Practising Responsible Tourism: International Case Studies in Tourism Planning, Policy and Development, Chichester: John Wiley \& Sons.

Harriss, J. (2005), 'Great promise, hubris and recovery: A participant's history of development studies', in U. Kothari (ed.) A Radical History of Development Studies: Individuals, Institutions and Ideologies, London: Zed Books, pp. 17-46.

Haywood, K. (1988), 'Responsible and responsive tourism planning in the community', Tourism Management, 9(2), 105-18.

Held, D. (2010), Cosmopolitanism Ideals and Realities, Malden: Polity Press.

Hettne, B. (2009), Thinking about Development, London: Zed Books.

Høivik, T. and Heiberg, T. (1980), 'Centre-periphery tourism and self-reliance', International Social Science Journal, 32(1), 69-98.

Holden, A. (2013), Tourism, Poverty and Development, Abingdon: Routledge.

Holden, P. (1984), Alternative Tourism with a Focus on Asia, Bangkok: Ecumenical Coalition on Third World Tourism.

Høyer, K. (200o), 'Sustainable tourism or sustainable mobility? The Norwegian case', Journal of Sustainable Tourism, 8(2), 147-6o.

Hunter, C. (1995), 'On the need to reconceptualise sustainable tourism development', Journal of Sustainable Tourism, 3(3), 155-65.

Husbands, W. (1981), 'Centres, peripheries, tourism and socio-spatial development', Ontario Geography, 17, 37-6o.

ICRT (2010), Cape Town Declaration, International Centre for Responsible Tourism. Accessed 5 February 2018 at http://responsibletourismpartnership.org/cape-town-declaration-on-responsible -tourism/

Inskeep, E. (1991), Tourism Planning: An Integrated and Sustainable Development Approach, New York: Van Nostrand Reinhold.

Jafari, J. (1989), 'Sociocultural dimensions of tourism: An English language literature review', in J. Bystrzanowski (ed.) Tourism as a Factor of Change: A Sociocultural Study, Vienna: Vienna Centre, pp. 17-6o. 
Jamal, T. and Dredge, D. (2016), 'Tourism and community development issues', in R. Sharpley and

D. Telfer (eds) Tourism and Development: Concepts and Issues, 2nd edn, Bristol: Channel View Publications, pp. 178-204.

Jenkins, C. (1991a), 'Tourism development strategies', in L. Lickorish (ed.) Developing Tourism Destinations, Harlow: Longman, pp. 61-77.

Jenkins, C. (1991b) 'Tourism and development', in L. Lickorish (ed.) Developing Tourism Destinations, Harlow: Longman, pp. 79-89.

Joppe, M. (1996), 'Sustainable community tourism development revisited', Tourism Management, 17(7), 475-9.

Kerr, W. (2003), Tourism Public Policy, and the Strategic Management of Failure, Oxford: Elsevier.

Knutsson, B. (2009), 'The intellectual history of development: Towards a potential widening repertoire', Perspectives No. 13, Gothenburg: School of Global Studies. Accessed 29 December 2017 at www. gu.se/digitalAssets/1272/1272997_Perspectives_13.pdf

Lane, B. (1990), 'Sustaining host areas, holiday makers and operators alike', Conference Proceedings, Sustainable Tourism Development Conference, Queen Margaret College, Edinburgh, November.

Law, C.M. (1992), 'Urban tourism and its contribution to economic regeneration', Urban Studies, 29(3-4), 599-618.

Lazarus, J. (2008), 'Participation in poverty reduction strategy papers: Reviewing the past, assessing the present and predicting the future', Third World Quarterly, 29(6), 1205-21.

Lea, J. (1988), Tourism and Development in the Third World, London: Routledge.

Leiper, N. (1990), Tourism Systems: An Interdisciplinary Perspective, Palmerston North, New Zealand: Massey University Printery.

Leiper, N. (1999), 'A conceptual analysis of tourism-supported employment which reduces the incidence of exaggerated, misleading statistics about jobs', Tourism Management, 2o(5), 605-13.

Lupoli, C., Morse, W., Bailey, C. and Schelhas, J. (2014), 'Assessing the impacts of international volunteer tourism in host communities: A new approach to organizing and prioritizing indicators', Journal of Sustainable Tourism, 22(6), 898-921.

Lyons, K., Hanley, J., Wearing, S. and Neil, J. (2012), 'Gap year volunteer tourism: Myths of global citizenship?', Annals of Tourism Research, 39(1), 361-78.

Mabogunje, A. (1980), The Development Process: A Spatial Perspective, London: Hutchinson.

McKercher, B. (1993), 'Some fundamental truths about tourism: Understanding tourism's social and environmental impacts', Journal of Sustainable Tourism, 1(1), 6-16.

Mihalič, T. (2015), 'Tourism and economic development issues', in R. Sharpley and D. Telfer (eds) Tourism and Development: Concepts and Issues, 2nd edn, Bristol: Channel View Publications, pp. 77-117.

Morakabati, Y., Beavis, J. and Fletcher, J. (2014), 'Planning for a Qatar without oil: Tourism and economic diversification, a battle of perceptions', Tourism Planning and Development, 11(4), 415-34.

Mowforth, M. and Munt, I. (2016), Tourism and Sustainability: Development, Globalisation and New Tourism in the Third World, 4th edn, Abingdon: Routledge.

Murphy, C. and Boyle, E. (2006), 'Testing a conceptual model of cultural tourism development in the post-industrial city: A case study of Glasgow', Tourism and Hospitality Research, 6(2), 111-28.

Murphy, P. (1983), 'Tourism as a community industry: An ecological model of tourism development', Tourism Management, 14(3), 180-93.

Murphy, P. (1985), Tourism: A Community Approach, London: Routledge.

Nash, D. (1989),'Tourism as a form of imperialism', in V. Smith (ed.) Hosts and Guests: The Anthropology of Tourism, 2nd edn, Philadelphia, PA: University of Pennsylvania Press, pp. 37-52.

ONS (2017), Travel Trends 2016, Office for National Statistics. Accessed 2 January 2018 at www.ons. gov.uk/peoplepopulationandcommunity/leisureandtourism/articles/traveltrends/2016

Opperman, M. and Chon, K. (1997), Tourism in Developing Countries, London: International Thomson Business Press. 
Page, S. and Hall, C.M. (2003), Managing Urban Tourism, Harlow: Prentice Hall.

Payne, A. and Phillips, N. (2010), Development, Cambridge: Polity Press.

Peet, R. and Hartwick, E. (2015), Theories of Development: Contentions, Arguments, Alternatives, New York: Guilford Press.

Pieterse, J. (1998), 'My paradigm or yours? Alternative development, post-development, reflexive development', Development and Change, 29(2), 343-73.

Pigram, J. (1990), 'Sustainable tourism: Policy considerations', Journal of Tourism Studies, 1(2), 2-9.

Pollock, A. (2012), 'Conscious travel: Signposts towards a new model for tourism', in 2nd UNWTO Ethics and Tourism Congress: Conscious Tourism for a New Era. September 12th, Quito. Accessed 6 February 2018 at http://3rxg9qea18zhtl6s2u8jammft.wpengine.netdna-cdn.com/wp-content/uploads/2012/o9/ presentacion-anna-meira-pollock.pdf

Porter, M., Stern, S. and Artavia Loría, R. (2013), Social Progress Index 2013, Washington, DC: Social Progress Imperative.

Pretty, J. (1995), 'The many interpretations of participation', Focus, 16(4), 4-5.

Rahnema, M. (1997), 'Towards post-development: Searching for signposts, a new language and new paradigms', in M. Rahnema and V. Bawtree (eds), The Post-Development Reader, London: Zed Books, pp. $377-403$.

Raymond, E. and Hall, C.M. (2008), 'The development of cross-cultural (mis)understanding through volunteer tourism', Journal of Sustainable Tourism, 16(5), 530-43.

Redclift, M. (1987), Sustainable Development: Exploring the Contradictions, London: Routledge.

Rist, G. (2014), The History of Development: From Western Origins to Global Faith, 4th edn, London: Zed Books.

Roberts, L. and Hall, D. (eds) (2001), Rural Tourism and Recreation: Principles to Practice, Wallingford: CABI.

Roche, M. (1992), 'Mega-events and micro-modernisation: On the sociology of new urban tourism', British Journal of Sociology, 43(4), 563-60o.

Rostow, W. (1967), The Stages of Economic Growth: A Non-Communist Manifesto, 2nd edn, Cambridge: Cambridge University Press.

Ruhanen, L. (2013), 'Local government: Facilitator or inhibitor of sustainable tourism development?', Journal of Sustainable Tourism, 21(1), 80-98.

Scheyvens, R. (2002), Tourism for Development: Empowering Communities, Harlow: Pearson Education.

Scheyvens, R. (2015), 'Tourism and poverty reduction', in R. Sharpley and D. Telfer (eds) Tourism and Development: Concepts and Issues, 2nd edn, Bristol: Channel View Publications, pp. 118-39.

Seers, D. (1969), 'The meaning of development', International Development Review, 11(4), 2-6.

Seers, D. (1977), 'The new meaning of development', International Development Review, 19(3), 2-7.

Sen, A. (1999), Development as Freedom, New York: Anchor Books.

Sharpley, R. (200o), 'Tourism and sustainable development: Exploring the theoretical divide', Journal of Sustainable Tourism, 8(1), 1-19.

Sharpley, R. (2002), 'The challenges of economic diversification through tourism: The case of Abu Dhabi', International Journal of Tourism Research, 4(3), 221-35.

Sharpley, R. (2003), 'Tourism, modernization and development on the island of Cyprus: Challenges and policy responses', Journal of Sustainable Tourism, 11(2-3), 246-65.

Sharpley, R. (2009), Tourism, Development and the Environment: Beyond Sustainability, London: Earthscan.

Sharpley, R. (2012), 'Responsible tourism: Whose responsibility?', in A. Holden and D. Fennel (eds) Handbook of Tourism and the Environment, Abingdon: Routledge, pp. 382-91.

Sharpley, R. (2015), 'Tourism: A vehicle for development?', in R. Sharpley and D. Telfer (eds) Tourism and Development: Concepts and Issues, 2nd edn, Bristol: Channel View Publications, pp. 3-3o.

Sharpley, R. (2018), 'Responsible volunteer tourism: Tautology or oxymoron? A comment on Burrai and Hannam', Journal of Policy Research in Tourism, Leisure and Events, 10(1), 96-100. 
Sharpley, R. and Telfer, D. (eds) (2015), Tourism and Development: Concepts and Issues, 2nd edn, Bristol: Channel View Publications.

Shaw, G. and Williams, A. (1994), Critical Issues in Tourism: A Geographical Perspective, Oxford: Blackwell.

Sidaway, J. (2007), 'Spaces of post-development', Progress in Human Geography, 3(3), 345-61.

Simpson, K. (2004), 'Doing development: The gap year, volunteer-tourists and a popular practice of development', Journal of International Development, 16(5), 681-92.

Simpson, M. (2007), 'Community benefit tourism initiatives: A conceptual oxymoron?', Tourism Management, 29(1), 1-18.

Sin, H. (2010), 'Who are we responsible to? Locals' tales of volunteer tourism', Geoforum, 41(6), 983-92.

Sinclair, M.T. (1998), 'Tourism and economic development: A survey', Journal of Development Studies, 34(5), 1-51.

Smeral, E. (2006), 'Tourism satellite accounts: A critical assessment', Journal of Travel Research, 45(1), $92-8$.

Smith, V. and Eadington, W. (eds) (1992), Tourism Alternatives: Potentials and Problems in the Development of Tourism, Philadelphia, PA: University of Pennsylvania Press.

Telfer, D. (2015), 'The evolution of development theory and tourism', in R. Sharpley and D. Telfer (eds) Tourism and Development: Concepts and Issues, Bristol: Channel View Publications, pp.31-73.

Telfer, D. and Sharpley, R. (2016), Tourism and Development in the Developing World, 2nd edn, Abingdon: Routledge.

Telfer, D. and Wall, G. (200o), 'Strengthening backward economic linkages: Local food purchasing by three Indonesian hotels', Tourism Geographies, 2(4), 421-47.

Todaro, M. and Smith, S. (2014), Economic Development, 12th edn, Harlow: Pearson Education.

Torres, R. (2003), 'Linkages between tourism and agriculture in Mexico', Annals of Tourism Research, 3o(3), 546-66.

Tosun, C. (2000), 'Limits to community participation in the tourism development process in developing countries', Tourism Management, 21(6), 613-33.

Tribe, J. (2005), The Economics of Leisure, Recreation and Tourism, Oxford: Elsevier.

Turner, L. and Ash, J. (1975), The Golden Hordes: International Tourism and the Pleasure Periphery, London: Constable.

UN (2015), The Millennium Development Goals Report 2015, United Nations. Accessed 3 January 2018 at www.un.org/millenniumgoals/2015_MDG_Report/pdf/MDG\%202015\%2orev\%20(July\%201).pdf

UN (2017), United Nations Sustainable Development Goals. Accessed 29 December 2017 at www. un.org/sustainabledevelopment/sustainable-development-goals/

UNDP (2010), Human Development Report 2010, New York: Oxford University Press.

UNWTO (2005), World Tourism Barometer 3(2), Madrid: UN World Tourism Organization.

UNWTO (2016), UNWTO Tourism Highlights, 2016 Edition, UN World Tourism Organization. Accessed 26 March 2017 www.e-unwto.org/doi/pdf/10.18111/9789284418145

UNWTO (2017a), World Tourism Organization: What We Do, UN World Tourism Organization. Accessed 14 December 2017 at www2.unwto.org/en\#

UNWTO (2017b), Tourism Highlights, 2017 Edition, UN World Tourism Organization. Accessed 2 January 2018 at www.e-unwto.org/doi/pdf/10.18111/9789284419029

UNWTO (2018), Sustainable Development of Tourism, UN World Tourism Organization. Accessed 2 February $2018 \mathrm{http}: / / \mathrm{sdt}$.unwto.org/content/about-us-5

Wall, G. and Mathieson, A. (2006), Tourism: Change, Impacts, Opportunities, Harlow: Pearson Education.

Wearing, S. (2001), Volunteer Tourism: Experiences that Make a Difference, Wallingford: CABI.

Wearing, S. and McGehee, N. (2013), 'Volunteer tourism: A review', Tourism Management, 38, 120-30. Wheeller, B. (1991), 'Tourism's troubled times: Responsible tourism is not the answer', Tourism Management, 12(2), 91-6. 
Williams, A. and Shaw, G. (eds) (1991), Tourism and Economic Development: Western European Experiences, London: Belhaven Press.

WTO (1980), Manila Declaration on World Tourism, Madrid: World Tourism Organization.

WTO (1998), Tourism: 2020 Vision: Influences, Directional Flows and Key Trends, Madrid: World Tourism Organization.

WTTC (2016), Travel and Tourism Economic Impact 2016 World, World Travel and Tourism Council. Accessed 2 January 2018 at www.wttc.org/-/media/files/reports/economic\%2oimpact\%2oresearch/regi ons\%202016/world2016.pdf

Young, G. (1973), Tourism: Blessing or Blight? Harmondsworth: Penguin.

Zhang, X., Song, H. and Huang, G.Q. (2009), 'Tourism supply chain management: A new research agenda', Tourism Management, 3o(3), 345-58. 